\title{
Anthropometric indices and its socio-demographic determinants among primary school children of an urban school in Pune, India
}

\author{
AK Yadav ${ }^{1}$, Atul Kotwal' ${ }^{2}$ R Vaidya ${ }^{3}$, Jyoti Yadav ${ }^{4}$
}

\section{AK Yadav', Atul Kotwal', R Vaidya ${ }^{3}$, Jyoti Yadav ${ }^{4}$}

${ }^{1}$ Clinical Epidemiological Unit, AlIMS, New Delhi, India

${ }^{2}$ Department of community medicine, ACMS, New Delhi, India

${ }^{3}$ Department of community medicine, ACMS, New Delhi, India

${ }^{4}$ Senior Medical Officer, Jaipur Golden

Hospital, New Delhi, India

\section{Correspondence}

Dr AK Yadav,

Clinical Epidemiology Unit, Room no, 91, AllMS, New Delhi

Phone no: 09868815430

Email: arunyadavpsm@gmail.com

\section{History}

- Submission Date: 14-01-2016;

- Review completed: 30-09-2016;

- Accepted Date: 14-10-2016.

DOI : 10.5530/ijmedph.2016.4.3

Article Available online

http://www.ijmedph.org/v6/i4

\section{Copyright}

(c) 2016 Phcog.Net. This is an openaccess article distributed under the terms of the Creative Commons Attribution 4.0 International license.

\begin{abstract}
Background: Health of the children (5-11yrs) is of importance not only as these children have already survived the most difficult phase of their life but also their future development will affect the development of entire society. Nationwide data on under five children is routinely collected during national surveys, such as National Family Health Survey (NFHS), similar data for school age children is usually not collected, except by individual worker. Hence it was decided to carry out a health survey for school children in urban area along with their social determinants and compare those with World Health Organization (WHO) standards. Aim: To find prevalence of malnutrition in primary school children of urban India and their social determinants. Setting and design: School community setting and cross sectional design. Material and Methods: Anthropometric measurements were done in students of class one to five by two investigators. A self administered questionnaire was used to collect information about socio-economic factors. Statistical analysis used: Epi Info 6 software of CDC, Atlanta, USA. Student ' $t$ ' test for quantitative data along with $95 \%$ confidence interval and chi square test for categorical data. Results: The prevalence of stunting was $4.47 \%$ (95\% Cl, 3-5.94), wasting 6.32\% (95\% Cl 4.59-8.05\%) and under nutrition $5.00 \%(95 \% \mathrm{Cl}$ 3.45-6). Parent's educational levels were significantly associated with the nutritional status of the child. However no statistically significant association was found with regard to family income and family size. Only wasting was significantly associated with mother's working status. Conclusion: Mothers and fathers education are most important determinants of nutritional status of primary school children in Urban India.
\end{abstract}

Key Words: Anthropometry, Nutritional status, Mother's education, Father's Education, India, Primary School

Key Message: Malnutrition is prevalent in primary school children. Mothers and fathers education are two most important determinants.

\section{INTRODUCTION}

Children embody hopes and aspirations for our future. They are the most vulnerable section of the society. While the worst form of malnutrition affects preschool children, it arrests the physical and mental development of school age children which has both immediate and long term consequences. The implications are decreased school performances, lower IQ levels, poor psychosocial development, decreased cognitive functions and reduced adult size leading to decreased economic productivity. ${ }^{1}$ The Government of India has shown renewed interest in the health status of school children by launching a program for their screening. ${ }^{2}$ Anthropometry remains one of the best methods to assess the nutritional status of the community, especially in a developing country like India. ${ }^{3}$ If these are recorded over a period of time in population, they may reflect the socio-economic development of the population. ${ }^{4}$

The United Nations Educational Children's Fund (UNICEF) report on nutrition status of under five children in the world reveals that percentage of under five children suffering from underweight, wasting and stunting is $27 \%, 8 \%$ and $31 \%$ respectively. ${ }^{5}$ It also revealed that percentage of children suffering from malnutrition in India is even more than those in Sub-Saharan Africa. One of the largest studies of anthropometric status of rural school children in low income countries (Ghana, Tanzania, Indonesia, Vietnam and India) found the overall prevalence of stunting and underweight to be high in all five countries, ranging from $48-56 \%$ for stunting and from $34-62 \%$ for underweight. ${ }^{6}$

In India, though nationwide data on under five children is routinely collected during national surveys, such as National Family Health Survey (NFHS),
Cite this article : Yadav AK, Kotwal A, Vaidya R, Yadav J. Anthropometric indices and its socio-demographic determinants among primary school children of an urban school in Pune, India. Int J Med. Public Health. 2016;6(4):160-4. 
similar data for school age children is usually not collected, except by individual worker. They have found prevalence of malnutrition ranges from $26 \%$ to $83 \%$ in rural and poor socio-economic settings ${ }^{7-15}$ and $5-19 \%$ in higher economic group and well to do settings. ${ }^{16-20}$ However only a few studies have related prevalence of malnutrition with their social determinants. Hence the present study was carried out to determine prevalence of malnutrition and their determinants among primary school children in the age group 5-11 years in an urban area of India.

\section{MATERIAL AND METHODS}

Pune is one of the major city located in the state of Maharashtra. The study was conducted in a Senior Secondary School of the Pune, located near institute. The school is a coeducational school. Most of the children studying in the school are wards of Government employee and lives within $10 \mathrm{Km}$ of school location. Each standard in school has four sections up to class V and six sections from class VI to XII and children are randomly allocated to different sections irrespective of sex, socioeconomic status or academic performance.

The study was carried out among children in the age group of 5-11 years studying in standard I of V of school. Sample size was calculated taking alpha error as $5 \%, \mathrm{p}=0.05$, expected deviation as $4 \%$. As per above assumptions the sample size calculated was 600 . All the children in the age group 5-11yrs (a total of 823 students) in the school were identified from the school records. The study was carried out from April 2009 to September 2009. Students those who had history of chronic or debilitating disease, children having single parent and those whose parent did not consent were excluded from the study. Finally 760 students were included in the study.

The study was given ethical clearance by ethical committee of institution. Permission of principal was taken before start of study. The aim and objectives of the study were told to parents during parent teacher meeting and their consent was taken. The parent who did not attend meeting was contacted on telephone for consent and consent form was given to student for completion. During examination, if students were found to be underweight, stunted or wasted, their parents were counseled and suitable advice was given to them.

Two investigators AKY and JY underwent training for two weeks for correct procedure for anthropometric measurements and anthropometric measurements were done by these two investigators. A questionnaire was prepared for gathering social information about mother's and father's education, income, family size and pretested in initial 30 students. Self administered questionnaire was given to the student and they were asked to return it in two days. These 30 students are included in final results.

Each child's height and weight was measured in the metric system, using standardized technique recommended by Jelliffe. ${ }^{21}$ Body weight was recorded with the help of an electronic weighing machine to the nearest 0.1 kilogram with their uniforms on, but without any footwear, belt or scarf. All the data were collected in between April and September when the uniform of school remains same (summer uniform). Electronic machine was standardized and calibrated on each measurement day. Height was measured with the help of stadiometer in the Frankfurt plane to the nearest $0.1 \mathrm{~cm}$. BMI was calculated using weight in kilogram divided by square of height in meter.

The parents of school children were government employee and have social security in the form of free medical care etc and are broadly classified into three groups according to the income and facilities provided to them. Socio-economic status was decided on the basis of these three categories. Category "A" includes the highest income group whose salary is more than $\$ 600$ per month. Category " $\mathrm{C}$ " includes whose income is lowest and is less than \$ (US dollar) 400 per month. Category " $\mathrm{B}$ ” includes those whose income fall in between these two i.e. $\$ 400$ per month to $\$ 600$ per month. Age of the child was determined using the school records. Mother's and father's education level was classified into five groups i.e. Illiterate (no formal education), Primary (completed class V), Middle School (completed class VIII), High School (Completed class X), Intermediate (Completed class XII) and Graduate and beyond (completed graduation or beyond), However for statistical purpose education up to high school (primary, middle and high school) were combined into one class as there were very few numbers in each category and there were no parent classified in illiterate group. Any mother, who was gainfully employed, with financial remunerations and was working for at least the past 12 months outside the house, was considered to be a working mother.

Data was analyzed using Epi Info 6 software of CDC, Atlanta, USA. Height for age (Stunted), Weight for height (Wasted), and Weight for age (Under weight) for each child was calculated and compared with the WHO/NCHS standard. Cut off point values between $( \pm)$ 2SD were considered normal $(3,22)$. The values less than $2 \mathrm{SD}$ but more than $3 \mathrm{SD}$ were considered moderately affected and values less than 3 SD were considered severely affected for stunted, wasted and underweight. Means and standard deviations were computed for all variables. Student 't'test was used for quantitative data and chi square test for categorical data. A statistical significant $\mathrm{p}$ value was taken as 0.05 .

\section{RESULTS}

Table 1 shows age and sex distribution, mean weight and mean height of children. Of the 760 children studied 309 (40.7\%) were females and 451(59.3\%) males. The boys and girls are homogenously distributed with respect to age group and sex (Chi square $=9.4$; $\mathrm{p}$ value $=0.15)$. The mean weight increased from $17.75 \mathrm{Kg}$ and $16.57 \mathrm{Kg}$ for boys and girls respectively in the $5+$ age group to $32.78 \mathrm{~kg}$ and 34.53 for boys and girls in the $11+$ age group respectively. The mean weight of boys was more than the girls except at 11 years of age. However there is no statistically significant difference in the mean weights of the boys and girls in any of the age groups. On comparison with NCHS/WHO standard the means weight of boys and girls of the present study was found to be lower in all age groups except at $9+$ in boys and 10+ in girls where study population has higher weight. The means height of girls was lower than that of the boys except at $8+$ years of age. This difference in the heights of the boys and girls was not significant in any age group.

As per the WHO/NCHS standards, 34 (4.47\%) children out of the total 760 children were stunted, with only three children showing severe grade of stunting (Table 2). Among the girls, 11 (3.56\%) were stunted as compared to $23(5.1 \%)$ boys. The boys and girls were homogeneously distributed with respect to grades of stunting ( $\mathrm{p}$ value $=0.7 \& 0.53$ ). Wasting was present in $48(6.32 \%)$ children. Wasting was observed in $22(7.11 \%)$ girls and $26(5.76 \%)$ boys, however this difference between sexes was not statistically significant ( $\mathrm{p}$ value $=0.55), 38(5 \%)$ children were underweight of which only one was severely underweight. Among the girls, $15(4.85 \%)$ were underweight, while 23 (5.10\%) boys were underweight ( $\mathrm{p}$ value $=0.99)$.

The highest prevalence of stunting 6.1\% was observed among children whose mother's were educated up to high school, while the lowest prevalence of stunting $2.5 \%$ was seen in children whose mother's were graduates or above (Table 3). The highest prevalence of wasting $8.5 \%$ was observed among children whose mothers were educated up to high school, while the lowest prevalence of wasting $3.9 \%$ was seen in children whose mothers were graduates or above (Table 3$)(p$ value $=0.02)$. The prevalence of underweight was least $2.5 \%$ among children whose mother's were educated till graduation or beyond, while prevalence 
Table 1: Comparison of mean weight and height of boys and girls

\begin{tabular}{|c|c|c|c|c|c|c|c|c|}
\hline \multirow{2}{*}{$\begin{array}{c}\text { Age group } \\
\text { (Years) }\end{array}$} & \multicolumn{3}{|c|}{ Boys } & \multicolumn{3}{|c|}{ Girls } & \multirow{2}{*}{$\begin{array}{l}\text { P value for diff in } \\
\text { mean weight of } \\
\text { boys and girls }\end{array}$} & \multirow{2}{*}{$\begin{array}{l}\text { P value for diff } \\
\text { in height of } \\
\text { boys and girls }\end{array}$} \\
\hline & $N$ & $\begin{array}{l}\text { Mean weight } \\
(\mathrm{Kg})(\mathrm{SD})\end{array}$ & $\begin{array}{l}\text { Mean height } \\
(\mathrm{cm})(\mathrm{SD})\end{array}$ & $\mathrm{N}$ & $\begin{array}{l}\text { Mean weight } \\
(\mathrm{Kg})(\mathrm{SD})\end{array}$ & $\begin{array}{l}\text { Mean height } \\
(\mathrm{cm})(\mathrm{SD})\end{array}$ & & \\
\hline $5-6$ & 32 & $17.8(2.7)$ & $109.5(5.1)$ & 28 & $16.6(1.8)$ & $108.8(5)$ & 0.05 & 0.6 \\
\hline $6-7$ & 66 & $19.5(3.2)$ & $114.1(6.5)$ & 34 & $18.2(3.2)$ & $111.8(5.8)$ & 0.06 & 0.08 \\
\hline $7-8$ & 74 & $22.8(4.1)$ & $121.3(8.5)$ & 36 & $20.9(6.6)$ & $117.8(9.9)$ & 0.06 & 0.06 \\
\hline $8-9$ & 85 & $26.3(4.8)$ & $127.6(6.2)$ & 54 & $26.3(5.3)$ & $129 \quad(6.9)$ & 0.9 & 0.2 \\
\hline $9-10$ & 94 & $30.6(7.2)$ & $135.3(6.5)$ & 69 & $29.6(7.8)$ & $134.5(7.5)$ & 0.4 & 0.4 \\
\hline $10-11$ & 77 & $32.5(7.1)$ & $141.4(6.5)$ & 73 & $32.9(8.9)$ & $140 \quad(7.9)$ & 0.7 & 0.3 \\
\hline $11-12$ & 23 & $32.8(6.4)$ & $143.9(6.8)$ & 15 & $34.5(5.8)$ & $142.2(6.6)$ & 0.4 & 0.5 \\
\hline
\end{tabular}

$\mathrm{N}=$ Number, $\mathrm{SD}=$ Standard Deviation

Table 2: Prevalence of stunting, wasting and underweight in study group according to WHO/NCHS standards

\begin{tabular}{cccccccccc}
\hline & \multicolumn{3}{c}{ Stunted } & \multicolumn{3}{c}{ Wasted } & \multicolumn{3}{c}{ Underweight } \\
\cline { 2 - 9 } & $\begin{array}{c}\text { Severe* } \\
\mathbf{N}(\%)\end{array}$ & $\begin{array}{c}\text { Moderate* } \\
\mathbf{N}(\%)\end{array}$ & $\begin{array}{c}\text { Total N (\%) } \\
95 \% \mathrm{Cl}\end{array}$ & $\begin{array}{c}\text { Severe* } \\
\mathbf{N}(\%)\end{array}$ & $\begin{array}{c}\text { Moderate* } \\
\mathbf{N}(\%)\end{array}$ & $\begin{array}{c}\text { Total (\%) } \\
95 \% \mathrm{Cl}\end{array}$ & $\begin{array}{c}\text { Severe* } \\
\mathbf{N}(\%)\end{array}$ & $\begin{array}{c}\text { Moderate* } \\
\mathbf{N}(\%)\end{array}$ & $\begin{array}{c}\text { Total (\%) } \\
95 \% \mathrm{Cl}\end{array}$ \\
\hline Girls & $1(0.3 \%)$ & $10(3.2 \%)$ & $11(3.6 \%)$ & $1(0.3 \%)$ & $21(6.8 \%)$ & $22(7.1 \%)$ & 0 & $15(4.9 \%)$ & $15(4.9 \%)$ \\
$(\mathrm{n}=309)$ & & & $(1.5-5.6)$ & & & $(4.3-10)$ & & $(2.5-7.3)$ \\
Boys & $2(0.4 \%)$ & $21(4.7 \%)$ & $23(5.1 \%)$ & $1(0.2 \%)$ & $25(5.5 \%)$ & $26(5.7 \%)$ & $1(0.2 \%)$ & $22(4.9 \%)$ & $23(5.1 \%)$ \\
$(\mathrm{n}=451)$ & & & $(3.1-7.1)$ & & & $(3.6-7.9)$ & & & $(3.1-7.1)$ \\
Total & $3(0.4 \%)$ & $31(4.1 \%)$ & $34(4.5 \%)$ & $2(0.3 \%)$ & $46(6.1 \%)$ & $48(6.3 \%)$ & $1(0.1 \%)$ & $37(4.9 \%)$ & $38(5 \%)$ \\
$(\mathrm{n}=760)$ & & & $(3-5.9)$ & & & $(4.6-8.1)$ & & & $(3.5-6.6)$ \\
\hline
\end{tabular}

${ }^{*}$ Values less than reference value minus $2 \mathrm{SD}$ and $3 \mathrm{SD}$ are taken as moderate and severe respectively. $\mathrm{N}=$ Number, $\mathrm{CI}=$ Confidence Interval

Table 3: Prevalence of stunting, wasting and underweight in study group according to socio-demographic variable

\begin{tabular}{|c|c|c|c|c|c|c|c|c|}
\hline Variable & Category & $\mathrm{N}$ & $\begin{array}{c}\text { Stunted N } \\
\text { (OR) }\end{array}$ & ${ }^{*}$ p value & $\begin{array}{c}\text { Wasted N } \\
\text { (OR) }\end{array}$ & ${ }^{*}$ p value & $\begin{array}{c}\text { Underweight } \\
\mathrm{N}(\mathrm{OR})\end{array}$ & ${ }^{*}$ p value \\
\hline \multirow[t]{3}{*}{ Mothers education } & Graduation and above & 279 & $7(1)$ & 0.04 & $11(1)$ & 0.02 & $7(1)$ & 0.03 \\
\hline & Intermediate & 151 & $7(1.84)$ & & $9(1.53)$ & & $10(2.76)$ & \\
\hline & High School & 330 & $20(2.51)$ & & $28(2.26)$ & & $21(2.64)$ & \\
\hline \multirow[t]{3}{*}{ Fathers education } & Graduation and above & 320 & $10(1)$ & 0.04 & $15(1)$ & 0.003 & $12(1)$ & 0.006 \\
\hline & Intermediate & 246 & $10(1.32)$ & & $10(0.87)$ & & $7(0.75)$ & \\
\hline & High School & 194 & $14(2.41)$ & & $23(2.73)$ & & $19(2.79)$ & \\
\hline \multirow[t]{3}{*}{ Socio-economic Status } & Cat A & 138 & $6(1)$ & 0.6 & $6(1)$ & 0.2 & $5(1)$ & 0.3 \\
\hline & Cat B & 57 & $1(0.42)$ & & $1(0.42)$ & & $1(0.5)$ & \\
\hline & Cat C & 565 & $27(1.12)$ & & $41(1.65)$ & & $32(1.58)$ & \\
\hline \multirow[t]{2}{*}{ Working status of Mother } & Working & 106 & $1(1)$ & 0.07 & $1(1)$ & 0.009 & $1(1)$ & 0.05 \\
\hline & Housewives & 654 & $33(0.2)$ & & $47(0.12)$ & & $37(0.16)$ & \\
\hline \multirow[t]{2}{*}{ Family size (members) } & $3-4$ & 573 & $28(1)$ & 0.3 & $36(1)$ & 0.9 & $32(1)$ & 0.2 \\
\hline & 5 or more & 187 & $6(1.54)$ & & $12(0.98)$ & & $6(1.8)$ & \\
\hline
\end{tabular}

${ }^{*} \mathrm{p}$ value of fisher exact test are used if any cell have value less than five. $\mathrm{N}=$ Number, $\mathrm{OR}=$ Odds Ratio

observed among children whose mother's were educated till intermediate and high school are $6.4 \%$ and $6.6 \%$ respectively.

Similarly all the three indices had statistically significant association with father's education (Table 3). Prevalence of stunting (7.2\%), wasting (11.9\%) and underweight (9.8\%) was highest among the children whose father's were educated till high school (Table 3 ).

The prevalence of stunting, wasting and underweight was higher among children whose mothers were housewives. However, this difference was only significant for wasting (Table 3 ).
The prevalence of stunting, wasting and underweight is homogenously distributed among three income group. However highest prevalence of stunting, wasting and underweight was seen in children of income group $<\$ 400$ (4.8\%, 7.1\% and 5.7\%) (Table 3).

In this study 78, 495, 153 and 34 families had family size of 3, 4, 5 and 6 or more. Family size does not show any statistically significant association with the three nutritional indices of stunting, wasting and underweight (Table 3). 


\section{DISCUSSION}

The mean weight and height of school children were more than the studies conducted in rural and underprivileged children ${ }^{7-15}$ but similar to other studies done in well to do setting in India. ${ }^{16-20}$ However when compared with reference standards laid down by NCHS/WHO they showed a growth lag. The prevalence of stunting, wasting and underweight as markers of under nutrition in our study were $4.47 \%, 6.67 \%$ and $5 \%$ of children respectively. Similar study conducted by Mukherjee et al 2008, Pune, India ${ }^{18}$ showed the prevalence of stunting, wasting and underweight to be $13.81 \%, 6.71 \%$ and $9.87 \%$ respectively. However lower prevalence has been reported in school-age children and adolescents from Maputo, Mozamique ${ }^{23}$.

Our finding that mother's education has statistically significant association with three indices to malnutrition has been reported by other workers also ${ }^{24-27}$ Data analysis of National Family Health Survey (NFHS) 3 also showed that mother's education has a strong independent effect on a child's nutritional status ${ }^{24}$ Further improvement in nutritional status with maternal education has been reported by other workers. ${ }^{13,28}$

Our study also showed father's education to be significantly associated with the three indices of malnutrition. However conflicting results have been shown by study done previously. Bishnoi et al, $2004^{25}$ and Dwivedi et al, $1992^{29}$ from India reported father's educational status to be related with nutritional status of children, however Gupta et al, 1991 from India $^{30}$ did not find any relation between fathers educational status and nutrition status of child.

NFHS III and Gopaldas et al ${ }^{27}$ observed that prevalence of stunting, wasting and underweight to be higher in children of working mother whereas study conducted by Mukherjee et al ${ }^{18}$ found prevalence to be lower in working mother. In our study we find prevalence to be lower in working mother though statistical significant only in case of wasting. In our finding prevalence may be lower in working mother this may be because of better social support present in our study population. In case both mother and father are working, there are elder either from maternal or paternal side to look after the children. Also this population is different from rural population and population of socio-economic weaker status in a sense that the mothers have helping hand (Maids) to perform household chorus.

In our study we did not find any significant association of socio-economic status and family size with indices of malnutrition. This is contrary to other studies conducted in India and elsewhere $(6,24-29)$. The probable explanation is the social security provided to our population in terms of medical, ration etc irrespective of socio-economic status and family size. Many researcher before have highlighted the direct and indirect effects of parental education on child malnutrition in India and elsewhere. ${ }^{30,31}$ Our study highlights that even in setting with good social support parental education (both mothers and fathers) may be associated with child malnutrition. This may be due to direct and indirect effect of parental literacy on food choices and consumption and also on utilization of health services. Hence parental literacy may be important to curb the public scourge of child malnutrition even in societies with good social support. The prevalence of the malnutrition among the children emphasize the need for routine checkup for children in school to identify nutritional deficit and bring them in contact with health care facility as early as possible.

The study has many limitations. Firstly study is conducted only in a primary school children of an urban area, wherein most of the parents of the children were government employees. Hence the representativeness of the study is limited. Secondly ideally anthropometric measurement should be done while the subject is naked or is minimally dressed. However in our study only shoes and belt were removed, hence actual weight may be less than what is measured. To minimize error in the study, it was conducted during summer time. Thirdly self reported questionnaire was administered for collection of socio-economic data and this questionnaire was carried by students and hence there is a likelihood of over reporting of socially desirable behavior.

\section{CONCLUSION}

This study highlights that malnutrition is prevalent in urban primary school children. The value of this study lies in the fact that children of this age group are available and amenable for early identification and intervention. Hence a routine health checkup for children is recommended even in this specialized group of population. Another important message is that education of mother's as well as father's has an association with nutrition status of children. Hence there may be scope of giving informal education to parents about food and nutrition, and school can play an important role in it by utilizing platforms such as parent teacher meeting. Further studies on effect of imparting nutritional education on parents on malnutrition of children is recommended to ascertain the findings.

\section{ACKNOWLEDGEMENT}

We acknowledge the help extending to us by parents and teachers in conduct of study. We thank the children for participation

\section{CONFLICTS OF INTEREST}

Authors declare that they have no conflict of interest.

\section{REFERENCES}

1. 4th Report - The World Nutrition Situation: Nutrition throughout the Life Cycle - rwns4.pdf [Internet]. [cited 2015 May 15]. Available from: http://www.unscn. org/layout/modules/resources/files.

2. Sonia Gandhi launches national child health screening programme - timesofindiaeconomictimes [Internet]. [cited 2015 Jan 15]. Available from: http://articles. economictimes.indiatimes.com/2013-02 06/news/36949971_1_child-healthprogramme-health-conditions.

3. WHO | Physical status: the use and interpretation of anthropometry [Internet] [cited 2015 Jul 15]. Available from: http://www.who.int/childgrowth/publications/physical_status/en/

4. Park K. Parks Textbook of Preventive and Social Medicine. 20th ed. Jabalpur: Banarasidas Bhanot: 2010

5. UNICEF - SOWC05 [Internet]. [cited 2016 Jan 15]. Available from: http://www. unicef.org/sowc05/english

6. The anthropometric status of schoolchildren in five countries in the partner ship for child development. Proc Nutr Soc. 1998 Feb;57(1):149-58. http://dx.doi. org/10.1079/PNS19980021; PMid:9571720.

7. Dattabanik ND, Nayar S, Krishna R, Lila R. A study of morbidity pattern nutritional status and various defects of urban primary school children in Delhi. Indian J Med Res. 1970; 37:561-64.

8. Gupta BS, Jain TP. A comprehensive study of the health status of rural and urban primary school children. Indian J Pediatr. 1973;40(303):135-41. http:// dx.doi.org/10.1007/BF02758149; PMid:4758007.

9. Srivastva DK, Thawarani YP, Gupta K. Health examination of primary school children at Gwalior, Part III. Anthropometric assessment. Indian Pediatr. 1978;15:671-9.

10. Rao P, Shastry GJ, Vijayraghavan K. Nutritional status of children in urban slums around Hyderabad City. Indian J Med Res. 1974;62(10):1492-8.

11. Patwari A. Health and nutritional status of school children in Kathua district Indian Pediatr 1979;16:797-802. PMid:536021.

12. Verma BL, Kumar A, Srivastava RN. Nutritional profile of children in rural community. Findings of two surveys. Indian J Public Health. 1980;24:140-9.

13. Verma M, Chhatwal J, Kaur G. Prevalence of anaemia among urban school children of Punjab. Indian Pediatr. 1998;35(12):1181-6. PMid:10216692.

14. Panda P, Benjamin Al, Singh S, Zachariah P. Health Status of school children in Ludhiana city. Indian J Community Med. 2000;25(4):150-5.

15. Goyal RC, Chavan UA. Health status of school children in Ahmednagar city Indian J Matern Child Health 1993;4(3):81-3.

16. Raghavan VK, Singh D, Swaminathan MC. Heights and weights of well nourished school children. Indian J Med Res. 1978;59(4):648-54.

17. Bhasin SK, Singh S, Kapil U, Sood VP, Gaur DR. Height and Weight of 'well to do' 
school children in Haryana. Indian Pediatr. 1990;27(10):1089-93. PMid:2090596.

18. Mukherjee R, Chaturvedi S, Bhalwar R. Determinants of nutritional status of school children. Med J Armed Forces India. 2008;64(3):227-31. http://dx.doi. org/10.1016/S0377-1237(08)80099-8.

19. Rath B, Ghosh S, Mohan M, Ramanujcharyulu TK. Anthropometric indices of children (5-15 Years) of a privileged community. Indian Pediatr. 1978;15(8):65365. PMid:312765.

20. Khadilkar WV, Khadilkar AV, Cole TJ, Sayyad MG. Cross sectional growth curves for height, weight and body mass index for affluent Indian children. Indian Pediatr. 2009:46:477-90. PMid:19556658.

21. Jelliffe DB. The assessment of the nutritional status of the community (with special reference to field surveys in developing regions of the world). Monogr Ser World Health Organ. 1966;53:3-271. PMid:4960818.

22. WHO_MONO_53_(part1).pdf [Internet]. [cited 2015 Jul 15]. Available from: http://apps.who.int/iris/bitstream/10665/41780/1/WHO_MONO_53_(part1).pdf.

23. Antonio P, Jose A, Maria, Damasceno A, Bueunen G. Anthropometric indicators of nutritional status; implications for fitness, activity and health in school age children and adolescent from Maputo, Mozambique. American J Clin Nutr, 2003;77(4):952-9.

24. National Family Health Survey [Internet]. [cited 2015 Jul 19]. Available from: http://rchiips.org/nfhs/report.shtml.
25. Bishnoi P, Sehgal S, Kwatra A. Anthropometric measurement of preschool children as affected by socio-economic factors. Asian Pacific J clinical nutrition. 2004; 13 (supplement) S132.

26. Ray SK, Biswas AK, Gupta SD, Mukherjee D, Kumar S, Biswas B et al. Determinants of nutritional status in children. Indian J Community Med. 2000(1): 7-10

27. Gopaldas T, Patel P, Bakshi M. Selected socio-economic environmental Maternal and child factors associated with the nutritional status of infants and toddlers. Food and nutritional Bulletin. 1998;10:29-34

28. Mishra VK, Retherford RD. Women's Education can improve Child Nutrition in India. NFHS Bulletin 2000;15:7-10.

29. Dwivedi SN, Banerjee N, Yadav OP. Malnutrition among children in and urban slum and its association. Indian J Matern Child health. 1992;3(3):79-81 PMid:12288815.

30. Gupta MC, Mehrotra M, Arora S, Saran M. Relation of childhood malnutrition to Parental education and mother's nutrition related KAP. Indian J Pediatr 1991:58(2):269-74. http://dx.doi.org/10.1007/BF02751136 ; PMid:1879910.

31. AL Kassouf, Senauer B. Direct and indirect effects of parental education on malnutrition among children in Brazil: a full income approach. Economic Development and Cultural Change, 1996;44(4):817-38. http://dx.doi.org/10.1086 1452246.

Cite this article : Yadav AK, Kotwal A, Vaidya R, Yadav J. Anthropometric indices and its socio-demographic determinants among primary school children of an urban school in Pune, India. Int J Med. Public Health. 2016;6(4):160-4. 